\title{
PRINCÍPIOS DA PRESUNÇÃO DE INOCÊNCIA E DA NÃO CULPABILIDADE: DISTINÇÃO, APLICAÇÃO E ALCANCE
}

\author{
Walter Nunes da Silva Júnior ${ }^{124}$
}

Recebido em: 05/06/2018

Aprovado em: 18/06/2018

\begin{abstract}
RESUMO
Malgrado se trate de princípio universal inerente aos sistemas jurídicos em geral, a presunção de inocência ou da não culpa culpabilidade só foi prevista em nosso meio na categoria de direito fundamental na Constituição de 1988. Mesmo assim diante da dicção normativa empregada pelo constituinte, há aceso debate na doutrina e na jurisprudência, notadamente quanto à efetiva nomenclatura da cláusula constitucional e o seu alcance. O diálogo com o Direito Comparado leva à conclusão de que, em verdade, o nosso sistema alberga o princípio da presunção de inocência como gênero, tendo como espécies os princípios da presunção da inocência stricto sensu e o da não culpabilidade. Em síntese, o primeiro, em proteção à honra e à imagem das pessoas, impede que haja o indiciamento, o ajuizamento da ação penal ou o recebimento da ação penal sem a existência de justa casa - materialidade indícios de autoria; o segundo, se faz sentir em relação aos pronunciamentos judiciais, quando, com a decisão, o juiz puder fazer juízo de culpabilidade. O princípio da presunção de inocência se aplica mais diretamente às atuações da autoridade policial e do Ministério Público, incidindo, ainda, nas decisões do juiz em que não está em causa o exame do mérito quanto à culpabilidade. Já o princípio da presunção de não culpabilidade rege essencialmente o agir do juiz, do qual deriva a parêmia in dubio pro reo, se e enquanto não houver um juízo de culpabilidade, especialmente no caso de condenação por tribunal, que exaure a discussão da matéria fática.
\end{abstract}

Palavras-chave: Presunção da inocência. Presunção da não culpabilidade. Distinção. Incidência. Extensão.

\section{INTRODUÇÃO}

\footnotetext{
${ }^{124}$ Doutor em Direito Constitucional pela Universidade Federal de Pernambuco (UFPE). Mestrado em Direito Público pela UFPE. Juiz Corregedor da Penitenciária Federal em Mossoró/RN. É professor associado da Universidade Federal do Rio Grande do Norte.
} 
Em meio à crise política e institucional que assola o país germinada dos casos de corrupção envolvendo especialmente chefes do executivo e parlamentares, dentre eles inclusive o Presidente da República e Senadores, voltou a frequentar a ordem do dia o debate sobre o alcance do princípio da presunção de não culpabilidade. Como será revelado, em nosso sistema jurídico sempre se entendeu que esse princípio, seja sob essa nomenclatura ou sob o nome de presunção de inocência, não era empecilho para a execução provisória, ou seja, determinar-se o cumprimento da pena pelo acusado, desde que existente condenação em segunda instância.

Mesmo tendo a Constituição de 1988 estabelecido que "ninguém será considerado culpado até o trânsito em julgado de sentença penal condenatória" (art. $5^{\circ}$, inciso LVII), a Suprema Corte manteve inalterada a sua jurisprudência tradicional a respeito do tema, em sucessivos e reiterados julgados.

Todavia, em 2009 houve uma reviravolta no trato dispensado ao tema, pois o Supremo Tribunal Federal, modificando a orientação anterior, firmou passo no entendimento de que, tendo em consideração como preceituado o princípio da presunção de inocência/não culpabilidade na Constituição, a decisão condenatória não pode surtir nenhum efeito quanto à prisão, senão após o trânsito em julgado do processo.

O novo entendimento firmado pelo Supremo Tribunal Federal não resistiu muito tempo. Logo em 2016, a Excelsa Corte voltou à orientação jurisprudencial que faz parte de sua tradição. Agora, sem que tenha havido nenhum fato novo a justificar mais uma alteração de entendimento, há sinais de que o Supremo irá modificar novamente seu entendimento.

O escopo perquirido com esse escrito é enfrentar as questões intrincadas sobre o assunto. Não há consenso na doutrina e na jurisprudência sequer quanto à nomenclatura correta do princípio. Afinal, o princípio esculpido em nossa Constituição é o da presunção de inocência ou o da não culpabilidade?

Quanto à indagação supra, aqui se sustenta a tese de que um princípio não se confunde com o outro: ambos existem e estão agasalhados dentre os direitos fundamentais. Para cumprir essa tarefa, o desenvolvimento da ideia começa com um bosquejo histórico sobre as origens do princípio, contemplando o tratamento normativo dispensado no Direito Comparado.

Em seguida, é feita abordagem quanto à posição da doutrina e da jurisprudência em relação à nomenclatura. No item 4 são apresentados os argumentos que conferem lastro ao entendimento de que os princípios da presunção de inocência e de não culpabilidade são diferentes e que eles se fazem sentir em momentos diferentes da persecução criminal, a partir 
da fase investigatória. Os itens 5 e 6 estão intimamente correlacionados, na medida em que se sustenta ser o princípio da presunção de inocência garantia voltada para inibir o indiciamento, em inquérito policial, ou a imputação, em processo criminal, sem que haja justa causa, daí por que se cuida de preceito que orienta, de regra, as atuações da autoridade policial e do Ministério Público. No item 7 começam as considerações propriamente ditas sobre o princípio da presunção de não culpabilidade, com a assertiva de que a verdade material e o in dubio por reo ou favor rei são seus corolários lógicos. O item 8 está reservado para evidenciar que o princípio da presunção de não culpabilidade desequilibra a relação processual em prol da defesa e, por fim, o 9 pontua a discussão sobre o alcance do princípio da presunção de não culpabilidade, o que exige a pré-compreensão do distinguish deste em relação ao da presunção de inocência e o tratamento que é dispensado no Direito Comparado, aí incluídos os diplomas internacionais.

\section{ORIGENS DO PRINCÍPIO DA PRESUNÇÃO DE INOCÊNCIA/DA NÃO CULPABILIDADE}

Antes de vicejarem as ideias revolucionárias e humanitárias propugnadas por BECCARIA, o acusado não possuía, sequer, o direito de defesa ${ }^{125}$. Embora aí já se identifique a semente do princípio da presunção de inocência, o pensamento filosófico de BECCARIA ficou mais claro, quando ele, com força cogente, reclamou que "Não se pode chamar um homem de réu antes da sentença do juiz, nem a sociedade pode retirar-lhe a proteção pública, senão quando tenha decidido que ele violou os pactos segundo os quais aquela proteção lhe foi outorgada." ${ }^{, 126}$.

Esse direito de não ser declarado culpado enquanto ainda há dúvida sobre se o cidadão é réu ou inocente, foi inserido dentre as declarações dos direitos do homem da Virgínia. O princípio foi albergado no art. 8. $^{\circ}$, com a seguinte dicção: "Em todos os processos criminais ou que impliquem na pena de morte, o réu tem direito... de ser julgado com presteza por um júri imparcial..., o qual só pode considerá-lo culpado pela unanimidade de seus membros..."

Seguindo essa orientação, na declaração de direitos fundamentais enxertada à Constituição americana, mais precisamente na Quinta Emenda, está dito que "Ninguém será

\footnotetext{
125 BECCARIA, Cesare. Dos delitos e das penas. Tradução Marcílio Teixeira. Rio de Janeiro: Editora Rio, p. 45.

${ }^{126}$ Ibid., p. 55. A palavra réu, utilizada por BECCARIA, certamente se confunde com a figura de condenado.
} 
levado a responder por um crime capital ou infamante a não ser mediante indiciamento ou denúncia por parte de um Grande Júri..."127. Sem embargo do que sobressai a uma interpretação literal do texto, VILE ${ }^{128}$ esclarece a essência do dispositivo em destaque e anota que ele, a despeito de estabelecer o sistema acusatório “... é baseado na presunção de que uma pessoa é legalmente inocente até que seja provada a sua culpa e que é melhor ter vários culpados livres do que um inocente condenado". Por conseguinte, mesmo sem a mesma clareza redacional, o princípio de que ninguém pode ser declarado culpado sem embasamento em uma determinada certeza continuou prestigiado.

Essa cláusula foi acolhida na Declaração Universal dos Direitos do Homem e do Cidadão de 1789, no seu art. $6^{\circ}$, sendo assim escrita: "Dado que todo homem deve ser presumido inocente até que tenha sido declarado culpado...”. Com a declaração francesa, empregou-se, pela primeira vez, a expressão presumido inocente, daí por que, nesse sentido, procede a afirmação de GRANDINETTI ${ }^{129}$, segundo a qual foi na célebre Declaração Universal dos Direitos do Homem e do Cidadão que apareceu, em um texto legal, o princípio com essa expressão.

Seguindo essa orientação, a Declaração Universal dos Direito do Homem, aprovada pela ONU em 1948, realçou, no art. 11, 1, que "Toda a pessoa acusada de um acto delituoso presume-se inocente até que a sua culpabilidade fique legalmente provada no decurso de um processo público em que todas as garantias necessárias de defesa lhe sejam asseguradas".

No Pacto Internacional sobre Direitos Civis e Políticos, aprovado em 91 de dezembro 1966, está plasmado no art. 14, 2, que "Toda pessoa acusada de um delito terá direito a que se presuma sua inocência enquanto não for legalmente comprovada sua culpa". No mesmo passo, a Convença Americana sobre Direitos Humanos de 1969, no art. 8, 2, primeira parte, reafirma, com ênfase, que "Toda pessoa acusada tem direito a que se presuma sua inocência enquanto não se comprove legalmente sua culpa"

\footnotetext{
${ }^{127}$ No original: "No person shall be held to answer for a capital, or other wise infamous crime, unlesson a presentment or indictment of a Grand Jury" Na tradução feita por COMPARATO: "Ninguém será considerado réu de um crime capital ou infamante a não ser mediante indiciamento ou denúncia de um júri de acusação (grand jury)...” (COMPARATO, Fábio Konder. A afirmação história dos direitos humanos. São Paulo: Saraiva, 1999, p. 108)

${ }_{128}$ VILE. John R. A companion to the united states constitution and its amendments. 3. ed. Library of Congress Cataloging-in-Publication Data, 2001. p. 157. (“... is base on the presumption that an individual is legally innocent until proven guilty, and that it is better for many guilty individuals to go free than for any innocent person to be falsely convicted."

${ }^{129}$ O processo penal em face da constituição. Rio de Janeiro: Forense, 1992, p. 70.
} 
Se no cenário internacional o princípio da presunção de inocência é consagrado desde as primeiras declarações dos direitos do homem ${ }^{130}$, no nosso sistema jurídico, até a entrada em vigor da Constituição de 1988, esse princípio somente existia de forma implícita, como decorrência da cláusula do devido processo legal (STF, HC 67707-0/RS. Rel. Ministro CELSO DE MELLO, Primeira Turma, j. em 07/11/80, DJ de 14/08/92, p. 12.225).

Não tendo merecido a atenção expressa das Cartas anteriores, a consagração desse princípio dentre os direitos fundamentais é uma das inovações da Constituição de 1988. Consoante a redação do art. $5^{\circ}$, LVII, "Ninguém será considerado culpado até o trânsito em julgado de sentença penal condenatória.” Parte dos doutrinadores identifica, aí, a chancela do que se convencionou chamar de princípio da presunção de inocência; outros acreditam que, em verdade, o dispositivo constitucional anuncia o princípio da presunção de não culpabilidade.

No Direito comparado, o princípio encontra guarida nos textos constitucionais dos países democráticos. Em investigação às Constituições que influenciaram mais de perto a elaboração da Carta Magna de 1988, observa-se que a Constituição da Espanha assegura, na qualidade de direito fundamental, que "Todos têm direito... à presunção de inocência." (art. 24, 2); a de Portugal que "Todo arguido se presume inocente até o trânsito em julgado da sentença de condenação...”; e a da Itália que "O acusado não é considerado culpado senão após a condenação definitiva"

Em resumo, nota-se desse bosquejo histórico do princípio em exame que a presunção de não culpabilidade foi pensada por BECCARIA e adotada nas Constituições do Estado da Virgínia e dos Estados Unidos com essa conotação. A despeito de nas declarações internacionais a nomenclatura adotada ter sido presunção de inocência, nos Estados Unidos, na Itália e no Brasil, o princípio foi catalogado como presunção de não culpabilidade.

Aliás, a dicção normativa eleita para o princípio pelo constituinte brasileiro é praticamente a mesma utilizada na Constituição italiana, circunstância que evidencia não só sua fonte inspiradora, como também que o constituinte brasileiro, embora fortemente influenciado pelas disposições da Constituição portuguesa, em relação ao preceito em causa, afastou-se expressamente da orientação lusitana ${ }^{132}$.

\footnotetext{
${ }^{130}$ A Declaração Universal dos Direitos do Homem, editada em 1948 pela ONU, a Convenção do Conselho da Europa e o Pacto de São José da Costa Rica falam, expressamente, no princípio da presunção de inocência.

${ }^{131}$ No original da Constituição italiana, o preceito assim está redigido "L'imputato no è considerato colpevole sino allá condanna definitiva."

${ }^{132}$ Essa origem direta do art. $5^{\circ}$, LVII, da Constituição de 1988 foi logo revelada pelo então juiz WÁLTER FANGANIELLO MAIEROVITCH (Presunção de não culpabilidade. In: Revista de Jurisprudência do Tribunal de Justiça do Estado de São Paulo. n. 126, p. 96.
} 
A escolha do constituinte brasileiro merece aplausos, pois, em verdade, nenhum país adota propriamente o princípio da inocência, porque isto inviabilizaria por completo o sistema processual, especialmente quanto às medidas de natureza cautelar. Se presunção de inocência houvesse, no desiderato de respeitar a essência desse princípio, para iniciar-se um processo, a prova quanto à participação do agente deveria ser idêntica àquela que dá a certeza material.

De toda sorte, tendo em consideração o diálogo da ordem jurídica nacional com o Direito Comparado e, especialmente, com as declarações internacionais, leva à conclusão de que, para todos os efeitos, sem embargado da nomenclatura empregada ou preferida pelo constituinte brasileiro, o nosso sistema adotado o princípio da presunção de inocência, que se apresenta mais abrangente do que o da presunção de não culpabilidade, sendo este apenas uma das espécies daquele.

\section{POSIÇÃO DA DOUTRINA E DA JURISPRUDÊNCIA QUANTO À NOMENCLATURA PRESUNÇÃo DE NÃO CULPABILIDADE OU PRESUNÇÃO DA INOCÊNCIA}

Costuma-se falar em princípio da presunção de inocência como preceito que se faz sentir no inquérito policial e no processo judicial, o que, como se tentará apresentar, não se mostra adequado. Com efeito, a Constituição não assegurou que todo homem é considerado inocente até a prova de sua culpabilidade, mas sim que ninguém será considerado culpado antes do trânsito em julgado de sentença criminal condenatória. constitucional, pois, em verdade, serve para defender o cumprimento de sua essência.

Há um certo paradoxo e mesmo irracionalidade na expressão presunção de inocência como garantia presente nos inquéritos e nos processos criminais, visto que isso significaria a impossibilidade de proceder-se à custódia preventiva e outras providências que têm como pressuposto a existência de elementos tidos como válidos para justificá-las, na medida em que elas não têm como lastro a prova da culpabilidade, mas sim apenas indícios de autoria. Para RUBIANES, melhor seria dizer que há, no processo criminal, mais uma presunção de culpabilidade do que de inocência, até porque, “... si se presume la inocência del imputado, pregunta el buen sentido,?por qué entonces procede contra él? "133 Não há de negar-se que a indagação do processualista italiano é inquietante.

${ }^{133}$ RUBIANES, Carlos. Manual de derecho procesal penal. Buenos Aires: Depalma, 1985. v 1, p. 77-78. 
A presunção de inocência, nesse sentido, entra em rota de colisão com a própria lógica garantista do sistema criminal. VÉLEZ MARICONDE ${ }^{134}$, na tentativa de contornar, doutrinariamente, essa incongruência, informa que não há, propriamente, a consagração de uma presunção de inocência, mas de um estado jurídico segundo o qual ele é inocente até que a sua culpabilidade seja declarada em uma sentença, o que não impede a imposição, durante o processo, de medidas embasadas na presunção de culpabilidade.

Acatando essa tese, RUBIANES ${ }^{135}$ diz que, para todos os efeitos, o acusado é considerado inocente durante o transcurso de todo o processo, situação jurídica que só se modifica após a declaração final da culpabilidade por meio da sentença, sem que isso impeça, porém, que “... en forma más o menos intensa, aparezca em el proceso uma presunción de culpabilidad, que justifique medidas em su contra." À objeção feita por CLARIÁ OLMEDO quanto a essa linha de raciocínio, sob o argumento de que, se o processo criminal em rigor contempla uma presunção de culpabilidade, isso implicaria afirmar que o ônus da prova em contrário caberia ao acusado, $\operatorname{RUBIANES}^{136}$ contrapõe que tal não ocorre, pois a acusação tem de transformar aquela presunção de culpabilidade em certeza de responsabilidade penal, sob pena de o estado de inocência continuar incólume. ${ }^{137}$

Referindo-se ao princípio da inocência declarado como direito fundamental do homem por diplomas internacionais e acatado no ordenamento jurídico colombiano ${ }^{1521}$, LONDOÑO JIMÉNEZ ${ }^{138}$ reconhece que, tal como se há entendido em sua plenitude, “... dicho principio no es fácil que tenga plena eficácia dentro del proceso penal” e admite que “... dados los actos jurídicos que necessariamente deben producirse dentro del proceso penal, a la luz de nuestra ley, queda la sensación de que la presunción es la contraria, es decir, la de culpabilidad." 139

O doutrinador colombiano constrói o pensamento de que, à medida que o processo judicial vai aprofundando-se em provas contrárias ao acusado, na mesma intensidade vai diminuindo a presunção de inocência. Ele diz que o princípio em referência vai destruindo-se gradualmente, “... por la situación de captura em estado de flagrancia o cuasiflagrancia, por una orden de captura escrita, por la indagatoria, por el auto de privación de la libertad, por el enjuiciamiento, por la comparecencia en la calidad de procesado a la audiência pública, por el

\footnotetext{
${ }^{134}$ Apud RUBIANES. Op. cit., p. 79.

135 Op. cit., p. 79.

136 Ibid. p. 79.

137 Art. $3^{\circ}$ do Código de Processo Penal colombiano: "Toda persona a quien se atribuya um heco punible se presume inocente mientras no se declare legalmente su responsabilidad em setencia ejecutoriada."

${ }^{138}$ Tratado de derecho procesal penal. Bogotá: Editorial Temis, 1989. t. 1, p. 17.

${ }^{1523}$ Ibid., p. 18

${ }^{139}$ Ibid., p. 18
} 
veredicto condenatório, etc". ${ }^{140}$ Meditando sobre o assunto, EUGENIO FLORIÁN ${ }^{141}$ aponta que, em muitas situações, devido à robustez da prova contra o acusado, a presunção de inocência pode descartarse y eliminarse, sem que isso se relacione, efetivamente, com “... ninguna presunción, sino que, por el contrario, encierra elementos de prueba que se manifiestan desde el comienzo y que revelan um estado de hecho desfavorable al acusado. Aqui la presunción de inocência está ausente, no por razones teóricas sino de hecho, o, por lo menos, tal presunción se vê rápidamente eleminada por elementos adversos."

Em crítica aos que defendem a presença do princípio da inocência como cláusula reitora do processo criminal, GIOVANE LEONE ${ }^{142}$ adverte que isso comporta uma inversão do sentido lógico e jurídico do sistema em si, daí por que é mais apropriado dizer que "Mientras hay um procedimiento en curso, no hay ni culpable ni inocente, sino unicamente indiciado: solo en el momento en que recaiga en la sentencia, se sabrá si el indiciado es culpable o inocente." De forma mais precisa, BETTIOL ${ }^{143}$, prestando atenção ao sistema italiano, verifica que, ao contrário da expressão utilizada no art. $6^{\circ}$ da Convenção europeia dos direitos do homem, a Constituição da Itália, no seu art. 27, não expressa tecnicamente uma presunção de inocência, pois, se assim fosse, diante da passividade do Ministério Público em produzir as provas suficientes para a condenação, o "juiz debería absolver al imputado porque a favor de este julgaria uma presunción de inocencia."

$\mathrm{Na}$ jurisprudência brasileira há julgados nominando o princípio de presunção de inocência e da não culpabilidade. O STJ, na Súmula 9, deu preferência à expressão presunção de inocência. O STF oscila entre uma nomenclatura e outra ${ }^{144}$.

\section{DISTINÇÃO ENTRE O PRINCÍPIO DA PRESUNÇÃO DE INOCÊNCIA E O DA NÃO CULPABILIDADE}

\footnotetext{
140 Ibid., p. 19

${ }^{141}$ Apud JIMÉNEZ. Op. cit., p. 19.

142 Ibid., p. 21.

${ }^{143}$ BETTIOL, Giuseppe. Instituciones de derecho penal y procesal. Tradução de Faustino Gutiérrez-Alviz y Conradi. Barcelona: Bosch Casa Editorial, 1973. p. 265.

${ }^{144}$ No STF: (a) julgados que adotam a nomenclatura princípio da presunção de não culpabilidade: HC, Primeira Turma, Rel. Ministro CELSO DE MELLO, j. 07.11.89, RTJ 141/816 e RT 690/380; HC 71.918-0, Rel. Ministro CARLOS VELlOSO, DJU 17.11.95, p. 39.206; HC 76.592-6, Segunda Turma, Rel. Ministro MAURÍCIO CORRÊA, DJU 30.10.98, p. 3; RHC, Segunda Turma, Rel. Ministro PAULO BROSSARD, j. 13.04.92, RTJ 142/254; HC 83.728, Primeira Turma, DJ 23.04.2004, p. 25; (b) julgado que adota o princípio da presunção de inocência: HC, Primeira Turma, Rel. Ministro MOREIRA ALVES, j. 26.4.94, RTJ 159/213; (c) julgados que utilizam as duas expressões: HC 81964 Primeira Turma, Rel. Ministro GILMAR MENDES, j. 10.12.2002, DJ 28.02.2003, p. 16. HC 80535 / SC, Primeira Turma, Rel. Ministro SEPÚLVEDA PERTENCE, J. 12.12.2000, DJ 02.03.2001, p. 03.
} 
Ainda que o constituinte brasileiro tenha adotado, expressamente, a orientação italiana, interpretação com base na ideia do transconstitucionalismo defendido por MARCELO NEVES ${ }^{145}$ permite asseverar que o nosso sistema alberga também o princípio da presunção de inocência. Questões de ordem lógica e mesmo jurídica conduzem à necessidade de que se faça a distinção entre os dois princípios, não sendo pertinente ou correto confundir um com o outro, como o faz a boa parte da doutrina.

Sem querer aqui apresentar uma visão reducionista o princípio sinaliza que, para a adoção de providências contrárias ao acusado, o juiz deve se lembrar de que há a presunção de inocência. Como decorrência desse princípio, para que seja autorizada decisão contrária ao acusado, exige-se que o juiz tenha apoio em provas inquebrantáveis. Os argumentos apresentados quanto à incongruência de um princípio da inocência residem, justamente, no fato de ser permitida a adoção de várias providências de ordem criminal contra uma pessoa, sem que contra ela se tenha a certeza de sua culpabilidade.

Note-se que, conquanto se exija um suporte probatório mínimo para que, pelo menos, seja instaurado um inquérito policial ${ }^{146}$ ou processo criminal contra alguém, sob pena de caracterização de constrangimento ilegal sanável por via do habeas corpus, em nenhum momento se garante à pessoa que ela somente poderá ser indiciada ou acusada caso se tenha prova de sua culpabilidade. Pelo contrário, a própria legislação entende que é suficiente, para que a pessoa seja indiciada ou denunciada, a existência de culpa sumária ou suporte probatório mínimo.

Por isso mesmo, a autoridade policial, ao fazer o indiciamento, não parte de nenhum juízo de certeza quanto à culpabilidade, do mesmo modo como procede o Ministério Público quando do oferecimento da denúncia. Para esses dois atores do sistema criminal, bastam a materialidade e indícios de autoria, o que significa dizer que, mesmo não tendo certeza da culpabilidade, eles devem levar adiante a persecutio criminis, assim como ocorre, até mesmo, em relação ao magistrado, quando chamado, em vários momentos antes do julgamento do processo, a decidir variadas questões.

Por imperativo de ordem lógica, parece paradoxal defender que a autoridade policial, o Ministério e o magistrado, conquanto devam ter em conta o princípio da presunção de

\footnotetext{
${ }^{145}$ Cf. NEVES, Marcelo. Transconstitucionalismo. São Paulo: Editora WMF Martins Fontes, 2009.

146 É importante ter presente a diferença entre instaurar inquérito e proceder ao indiciamento. Não raro, a autoridade policial instaura o inquérito sabendo, apenas, que ocorreu o ilícito, não tendo, em alguns casos, sequer um suspeito. Assim, em obediência ao princípio da obrigatoriedade, com base apenas na notícia de que um crime pode ter ocorrido, a autoridade policial instaura o inquérito. Todavia, para indiciar alguém ela precisa reunir não apenas provas que de fato o crime ocorreu, como também indícios de que aquela pessoa perpetrou o ilícito.
} 
inocência, estam autorizados, respectivamente, a indiciar, acusar e receber uma denúncia contra o agente, tudo isso tendo como suporte, apenas, a prova da materialidade e meros indícios de autoria.

Aliás, pertinente lembrar que, em diversos momentos do processo, para tomar uma decisão contrária aos interesses do acusado, o juiz não precisa do auxílio da verdade material. Como dito, a procedência dessa assertiva se mostra já na primeira decisão dada pelo juiz no processo, que diz respeito ao juízo de admissibilidade da denúncia. Nesse momento, o magistrado se contenta, para proferir decisão desfavorável aos interesses do réu, em observar se há elementos probatórios pertinentes à materialidade e indícios quanto à autoria. Para todos os efeitos, o juiz, ao receber a ação penal, está a dizer que, diante dos elementos probatórios coligidos durante a investigação, há indicativos de que o acusado realizou a conduta, devendo, portanto, ser apurada a sua culpabilidade, quando, mercê do princípio da presunção de não culpabilidade, se e somente se afastada dúvida razoável, poderá ser proferida sentença condenatória.

Ora, se o princípio fosse da inocência, ou mesmo se esse preceito se fizesse sentir em todo e qualquer momento do processo, o juiz, sem base em uma prova conclusiva quanto à culpabilidade, não poderia admitir a denúncia.Várias outras decisões dadas pelo julgador ao longo do processo em que não se exige a existência de prova da culpabilidade, a exemplo da decretação da prisão preventiva ${ }^{147}$.

Por imperativo lógico não se pode defender que, devido à exigência de culpa sumária para que alguém seja indiciado na esfera policial ou denunciado perante o juízo e mesmo para que o juiz admita a ação penal ou decrete a prisão processual, vigora nessas oportunidades o princípio da presunção de não culpabilidade, preceito que, conforme communis opinio doctorum, em ultima ratio, quer dizer que, presente dúvida razoável, o exegeta deva alvitrar a solução mais favorável ao agente a quem imputada a prática do ilícito. O que se quer evidenciar é que, nesses casos, o nome técnico correto é mesmo o da presunção de inocência, até porque a presunção de não culpabilidade somente vigora, em toda a sua essência, quando o juiz, com o seu pronunciamento, pude condenar o acusado.

Pode-se asseverar peremptoriamente que, quando o magistrado analisa um pedido principal ou incidental que não pode importar em conclusão quanto à culpabilidade do agente,

\footnotetext{
${ }^{147}$ Note-se que, mesmo sob a nomenclatura de princípio da presunção de não culpabilidade, o Supremo Tribunal Federal tem reconhecido que esse postulado tem como consequência a concepção de que a prisão processual possui natureza acautelatória, de modo que somente deve ser decretada em situações excepcionais, sem a necessidade de prova quanto à culpa em si (cf. HC 80.719, Primeira Turma, Rel. Ministro CELSO DE MELLO, j. 26/06/2001, DJ 28.09.02, p. 37). Cf. SILVA JÚNIOR. Walter Nunes da. Reforma tópica do processo penal, p. 436-439 e 451-455.
} 
o princípio que rege o assunto não é o da presunção de não culpabilidade. Tome-se como primeiro parâmetro o que ocorre na apreciação de toda e qualquer decisão interlocutória, e não apenas em relação àquela com a qual o juiz analisa o recebimento da denúncia. Nesses momentos processuais o juiz não decide se o acusado é, ou não, culpado, pelo que para decidir contra o interesse deste não há necessidade de que o decreto jurisdicional tenha como lastro a verdade material, sendo suficiente a formal, que se baseia na prova quanto à existência do crime e em indícios de autoria ${ }^{148}$. Em alguns casos, como na busca e apreensão, basta a suspeita de que a pessoa oculte arma proibida ou objeto relacionado a um crime (art. $240, \S 2^{\circ}$, do CPP).

Alguns doutrinadores sustentam que na hipótese aqui em foco o princípio aplicável é o do in dubio pro societate. Já defendemos essa posição. No entanto, no nosso sentir, esse entendimento emerge do erro em não se fazer a distinção entre a presunção de inocência e a de não culpabilidade. $\mathrm{O}$ que existe, em verdade, é a incidência do princípio da presunção de inocência no sentido estrito, significando apenas que, como o juiz nessa oportunidade não faz juízo de culpabilidade, para que a decisão seja desfavorável ao acusado, mostra-se bastante a existência de prova da materialidade do crime e de indício de autoria.

Todavia, o que mais reforça essa tese é quando se observa o que acontece em relação à absolvição sumária. No procedimento relativo ao tribunal do júri, tendo em conta que o juiz natural para o julgamento dos crimes dolosos contra a vida é o conselho de sentença, formado por pessoas leigas recrutadas da sociedade, a doutrina e a jurisprudência possuem posição consolidada no sentido de que o magistrado, na dúvida, deve pronunciar o acusado. Não sendo esse o caso, ele deve impronunciar, o que significa que a decisão somente faz coisa julgada formal, de modo que permite, enquanto não verificada a prescrição, a reabertura do caso, desde que coligidas novas provas sobre o fato ilícito. A absolvição sumária, que é a decisão com a qual o juiz diz que o acusado é inocente da acusação ou é inimputável, de acordo com o entendimento consolidado na doutrina e na jurisprudência, só é possível quando o juiz tiver a certeza da inculpabilidade ou da inimputabilidade, enfim, de uma das hipóteses do art. 415 do $\mathrm{CPP}^{149}$. Aqui, inverte-se a lógica do processo: para absolver, a decisão do juiz, na sua motivação, tem de estar acompanhada de prova robusta em prol do acusado - prova

\footnotetext{
${ }^{148}$ Podem ser mencionadas todas as medidas cautelares de ordem criminal (escuta telefônica, quebra de sigilo etc), a começar pela prisão preventiva.

149 “Art. 415: O juiz, fundamentadamente, absolverá desde logo o acusado, quando: I - provada AA inexistência do fato; II provado não ser ele autor ou partícipe do fato; III - o fato não constituir infração penal; IV demonstrada causa de isenção de pena ou de exclusão do crime."
} 
material. Em outras, há até mesmo uma inversão: para absolver exige-se a prova da inocência $^{150}$.

Tendo em consideração esse distinguish entre os princípios da presunção de inocência e o da não culpabilidade, tem-se que, para todos os efeitos, este último só está presente em sua essência nos momentos processuais em que o juiz, com a sua decisão, pode reconhecer a culpabilidade do denunciado. domesmomodo, a absolvição sumária prevista para os demais procedimentos, inovação introduzida com a primeira etapa da Reforma Tópica de $2008^{151}$, também é orientada pelo princípio da presunção de inocência. Como já tivemos a oportunidade de dizer, a absolvição sumária é “... uma decisão de exceção, que somente deve ser dada nas hipóteses em que o juiz está seguro, com base na robustez da prova, de que o acusado deve ser, independentemente da instrução do processo, desde logo absolvido."152

Essa característica é ínsita à revisão criminal, não apenas porque aqui há uma sentença condenatória transitada em julgado, mas porque na apreciação dessa espécie de ação não se pode condenar ou piorar a situação da pessoa. O mesmo ocorre em relação ao habeas corpus, de modo que, quando ele visa a extinção de processo sob o fundamento de que o acusado é inocente, para que seja decidido pela procedência do pleito, é preciso que a prova da inocência seja evidente ${ }^{153}$. Nessas situações o que se tem é a incidência do princípio da presunção de inocência em sentido estrito.

Por conseguinte, o mais apropriado é arrematar que o preceito encartado em nossa Constituição dá azo a que se enxergue nele não apenas uma presunção de não culpabilidade como, igualmente, uma presunção mesmo de inocência.

Em obséquio aos diplomas internacionais que conferem preferência à nomenclatura direito ao silêncio e, ademais, em compasso com o argumento da exigência da culpa sumária (materialidade e indícios de autoria) para o indiciamento ou a existência de um processo criminal, o mais correto é afirmar que, para todos os efeitos, essa expressão, lato sensu, engloba a presunção de inocência stricto sensu e a presunção de não culpabilidade.

\footnotetext{
${ }^{150}$ Cf. SILVA JÚNIOR. Walter Nunes da. Curso de processo penal: teoria (constitucional) do processo penal. 2. ed. Natal: OWL, p. 606-607.

151 Mais especificamente, em razão da redação determinada no art. 397 do CPP pela Lei no 11.719 , de 2008. A própria redação dos incisos do art. 397 do CPP demonstra que, exceto quanto à absolvição sumária com base na extinção da punibilidade, questão objetiva, nas demais hipóteses, o juiz precisa estar fulcrado em juízo de certeza. Vejam-se as expressões grifadas nos incisos 397 do CPP: "I - a existência manifesta de causa excludente de ilicitude do fato; II - a existência manifesta de causa excludente da culpabilidade do agente, salvo inimputabilidade; III - que o fato evidentemente não constitui crime; ou V - extinta a punibilidade do agente." (Grifamos).

${ }^{152}$ Cf. SILVA JÚNIOR, Walter Nunes da. Reforma tópica do processo penal: inovações aos procedimentos ordinário e sumário, com o novo regime das provas, principais modificações do júri e as medidas cautelares pessoais (prisão e medidas diversas da prisão), 2. ed. Rio de Janeiro: Editora Renovar, p. 171.

${ }^{153}$ STF, RHC 68.525/DF, Segunda Turma, Rel. Ministro Paulo Brossard, j. 13.04.92, DJ de 12.06.92, p. 9.028.
} 


\section{A PRESUNÇÃO DE INOCÊNCIA COMO GARANTIA CONTRA A INSTAURAÇÃo DE INQUÉRITO OU DE PROCESSO CRIMINAL SEM JUSTA CAUSA}

O princípio plasmado no art. $5^{\circ}$, LVII, da Constituição de 1988, como se ressaltou acima, diz respeito ao juízo de culpabilidade, de modo que ele, quanto ao seu campo de domínio maior, que é o da prova, somente se faz sentir quando o juiz se debruça sobre o caso para definir se o acusado é culpado ou inocente. Todavia, exegese desse princípio em consonância com a dignidade da pessoa humana, especialmente quanto à inviolabilidade da honra e da imagem e mesmo o diálogo com diplomas internacionais permite extrair do texto constitucional a presença do princípio da presunção de inocência stricto sensu, conforme pinçado supra.

Note-se que, consoante a doutrina e a jurisprudência brasileiras, para que alguém seja indiciado ou acusado em processo judicial, mister se faz que haja um suporte probatório mínimo que aponte a existência do crime e indícios de sua autoria. Assim além das três condições da ação clássicas, a ação penal tem uma quarta e específica condição, que é a justa causa $^{154}$.

Ainda que sem a melhor técnica, a modificação introduzida no Código de Processo Penal por obra da Lei 11.719, de 20 de junho de 2008, dá a entender que a justa causa é uma condição específica da ação penal, porquanto passa a ser considerada, ao lado da falta de pressuposto processual e da ausência da tríade condicional de toda e qualquer ação, uma das hipóteses de rejeição da denúncia ou queixa ${ }^{155}$.

A exigência de justa causa para o indiciamento em inquérito policial ou oferecimento da ação penal é uma garantia por demais importante, porque assegura que nenhuma pessoa será constrangida, por meio de inquérito ou de processo criminal, quanto ao seu direito de

\footnotetext{
${ }^{154}$ MARIA THEREZA MOURA não considera a justa causa uma das condições da ação, porquanto, para ela, a falta de uma das três condições da ação constitui-se, por si mesmo, em uma das hipóteses de falta de justa causa (MOURA, Maria Thereza Rocha de Assis. Justa causa para a ação penal: doutrina e jurisprudência. São Paulo: Revista dos Tribunais, 2001, p. 221).

${ }^{155}$ No nosso entendimentos, "Menos preocupado com o rigor científico do que com a realidade, o que se teve em mente, com a redação emprestada ao art. 395 do CPP, foi ressaltar que, no momento desse exame, o juiz, dentre os pressupostos processuais e as condições da ação, deve dar acentuado destaque exatamente para aqueles vícios que, mais frequentemente, são questionados no decorrer do processo, muitas vezes, até mesmo, por meio da interposição de habeas corpus." (SILVA JÚNIOR, Walter Nunes da. Reforma tópica do processo penal, p. 103.)
} 
liberdade e notadamente quanto à honra e a imagem, sem que existam contra ela provas de que o fato efetivamente ocorreu, assim como indícios que, se não autorizam a conclusão de sua culpa, justificam que ela seja apontada como a possível autora do fato criminoso.

Mas por que se precisa de justa causa para se indiciar ou acusar alguém? GIMAR MENDES, INOCÊNCIO MÁRTIRES e PAULO GONET ${ }^{156}$ ressaltam que o Supremo Tribunal Federal tem entendido que, diante dos danos que a mera existência de um processo criminal acarreta à dignidade pessoal do indivíduo, ocorre constrangimento ilegal quando a persecução penal é injusta.

É como se o sistema dissesse que todas as pessoas são presumidamente inocentes, daí por que, para que ela seja apontada como a provável autora de um crime, exige-se que essa imputação se faça com base em uma culpa sumária. Há mesmo, no sistema jurídico brasileiro, como efeito do princípio extraído do art. 5, inciso LVII, da constituição, uma presunção de que todas as pessoas são inocentes, de modo que elas não podem ser perturbadas com imputações criminosas, a não ser que essa afirmação, feita pela autoridade policial ou pelo Ministério Público, tenha como suporte um lastro probatório mínimo.

Para o cidadão, essa presunção de inocência é uma garantia no sentido de que ele não poderá ser perturbado em sua paz nem arranhado em sua dignidade como pessoa, tanto em sua honra quanto à sua imagem, com imputações levianas ou temerárias, invocadas sem a menor plausibilidade, com o propósito apenas de deixá-lo em situação constrangedora.

Para os órgãos do Estado encarregados da persecução criminal, a presunção de inocência, na perspectiva aqui sustentada, impõe uma limitação quanto a essa atuação, na medida em que exige a necessidade de que a imputação criminosa tenha como lastro uma prévia reunião de elementos probatórios a respeito da materialidade e autoria do delito, ou seja, haja justa causa para a persecução criminal.

\section{A VERDADE MATERIAL, IN DUBIO PRO REO OU FAVOR REI COMO DECORRÊNCIA DO PRINCÍPIO DA NÃO CULPABILIDADE E SEU ALCANCE EM RELAÇÃO À PROVA}

Do princípio da presunção de não culpabilidade é que decorre o do in dubio pro reo, o que leva à conclusão de que a regra que determina o magistrado a decidir, na dúvida, em favor

\footnotetext{
${ }^{156}$ MENDES, Gilmar Ferreira; BRANCO, Paulo Gustavo Gonet. Curso de direito constitucional. 6. ed. São Paulo: Saraiva, 2007, p. 529.
} 
do acusado, somente se aplica quando ele estiver para julgar sobre a culpabilidade ou não. Em outra análise, esse princípio insere, no âmbito do processo criminal, o que se convencionou chamar favor rei ou de verdade material. Tal princípio consagra a máxima construída pela inteligência de CARRARA ${ }^{157}$ ao ensinar que, para a sociedade, era preferível absolver um culpado do que condenar um inocente, até porque, se outro não fosse o motivo, a condenação do inocente representa um mal concreto e real, enquanto a absolvição do culpado tem apenas a potencialidade de causar um perigo de lesão social.

Conquanto o alcance do princípio sirva para estruturar o próprio sistema criminal no sentido de privilegiar e dar maior tutela na relação processual ao direito de liberdade do acusado, a repercussão mais direta do princípio da presunção de não culpabilidade incide quanto à determinação de sobre quem recai o ônus da prova e da força que lhe deve ser dada. Consectário lógico do princípio da não culpabilidade é que o juiz, para condenar alguém, deve escorar-se na verdade real ou material ${ }^{158}$, uma vez que, na dúvida, ele deve aplicar o favor rei ou o brocardo do in dubio pro reo.

Quanto ao Ministério Público, a repercussão do princípio da presunção de não culpabilidade é no sentido de que ele tem o ônus de produzir a prova material, ou seja, ele tem o dever de provar, enquanto à defesa se revela bastante plantar dúvida razoável quanto à ocorrência do crime e ou participação ou culpabilidade do acusado.

A verdade material ou aquela que afasta a dúvida razoável como princípio reitor do processo criminal se baseia na premissa de que não interessa à sociedade encontrar um culpado, mais sim $o$ culpado, pois a área de segurança afetada com a ação ilícita somente terá possibilidade de ser recuperada ou ter amenizado o gravame a ela causado, caso o verdadeiro responsável pelo delito seja chamado a sua responsabilidade.

Todavia, não raro, no processo penal, a decisão é tomada com base em uma verdade meramente formal e, em alguns casos, ela é, até mesmo, consensuada, como ocorre nas hipóteses de transação e de suspensão condicional do processo, inclusive no caso de colaboração premiada. Ninguém dirá que, quando o juiz, em obséquio ao princípio da não culpabilidade, absolve o acusado por insuficiência de provas, a sentença se apoia na verdade material. A sentença absolutória, é claro, pode até ser proferida com suporte em uma verdade material, mas, para todos os efeitos, sempre e sempre o juiz está autorizado a exarar sentença

\footnotetext{
157 CARRARA, Francesco. Programa do curso de direito criminal. Tradução de Ricardo Rodrigues Gama. Campinas: Editora LZN, 2002. v. 2. p. 292-293.

${ }^{158}$ A verdade material, em sua essência, quer dizer que o juiz, ao julgar, deve estar o mais aproximado possível da realidade fática que permeia o caso.
} 
absolutória ainda que sem a certeza da inocência; a contrario sensu, basta que ele não tenha base em prova material para condenar.

Como se vê, não é correto asseverar que o processo criminal é inteiramente regido pelo princípio da verdade material. O que se pode e deve afirmar é que decorre do princípio da presunção de não culpabilidade a assertiva de que o Ministério Público, para conseguir a procedência de sua pretensão acusatória, tem o ônus de comprovar os fatos constitutivos do dever-poder de punir, porquanto o juiz somente pode condenar o agente com base na certeza de que ele é culpado. Sob outro ângulo, pode-se dizer que o princípio da não culpabilidade dá ao acusado o direito de ter uma sentença absolutória que não tem como certa a sua inocência, mas sim a dúvida de que ele seja culpado, ou não.

\section{O PRINCÍPIO DA PRESUNÇÃO DE NÃO CULPABILIDADE E A SUA REPERCUSSÃO NO TRATAMENTO DADO Às PARTES NA RELAÇÃo PROCESSUAL}

Por mais legítimo que seja o exercício do dever-poder de punir, ainda que se enxergue nele mais um direito coletivo da sociedade ${ }^{159}$ do que um mero interesse estatal, o acusado tem de merecer, pelo menos, um tratamento igualitário. Até porque na relação jurídica instaurada com o processo penal, existem dois direitos fundamentais coletivos que suscitam as maiores preocupações dos cidadãos e do Estado: de um lado, o dever-poder de punir e, do outro, o direito de liberdade.

Em essência, verifica-se no processo penal uma colisão de direitos fundamentais: o dever-poder de punir representa os direitos fundamentais na perspectiva objetiva, enquanto os limites a essa missão estão consubstanciados na dimensão subjetiva dos direitos fundamentais. A solução desse hard case se faz mediante a técnica da ponderação, partindo da premissa de que os conflitos das normas constitucionais devem ser resolvidos em consonância com as circunstâncias de cada caso concreto, exigindo-se do intérprete o adequado balanceamento dos bens, interesses e valores tutelados pelos direitos fundamentais envolvidos.

\footnotetext{
${ }^{159}$ A ação penal é uma ação coletiva, na qual o Ministério Público substitui o grupo social, que tem o interesse no descobrimento da verdade e que seja buscada a responsabilidade penal mais adequada ao restabelecimento da ordem pública.
} 
Sob outro aspecto, a mera existência do processo penal, sem embargo de macular a imagem da pessoa perante a sociedade, importa, no mínimo, em ameaça ao direito de liberdade $^{160}$. Nesse sentido, GILMAR MENDES, INOCÊNCIO MÁRTIRES e PAULO GONET $^{161}$ esclarecem que a persecução criminal injusta ofende o princípio da dignidade da pessoa humana, a par de essa ofensa ser potencializada, na medida em que ameaça a esfera da liberdade de locomoção ${ }^{162}$.

Assim, a preservação dos direitos fundamentais, nas perspectivas objetiva e subjetiva interessam de perto a todos os cidadãos, e não apenas agente que está se defendendo no processo. Isso porque em dimensão última tanto o dever-poder de punir quanto o de liberdade, honra e imagem possuem gênese coletiva, dai que não é adequado dizer que o dever de punir, por representar um interesse coletivo, deve receber mais prestígio do que o direito de liberdade do acusado. culpabilidade, que veicula a parêmia de que, na dúvida, o juiz deve decidir em prol do acusado.

O mestre CARRARA, discípulo de BECCARIA e que assumiu para si a missão de fazer as deduções jurídicas da primeira escola penal, construiu a sua teoria tendo como suporte a conclusão de que, para a sociedade, é menos pernicioso absolver um culpado do que condenar um inocente ${ }^{163}$. Com essa assertiva, ele disse, com todas as letras, que, entre a tutela da liberdade do acusado e a do dever-poder de punir, deve prevalecer a primeira. il professore $\operatorname{arrematava}^{164}$ :

(...) ao mal real da condenação do inocente volta a reunir-se um duplo perigo também para os associados: $1^{\circ}$, o perigo de que o verdadeiro culpado, assim conservado impune, extraia daí incitamento a novas lesões do direito. $2^{\circ}$ o perigo que pesa sobre cada um de ser, por sua vez, vítima de um erro judiciário, pelo qual os cidadãos hesitam entre o temor dos crimes e o temor das aberrações judiciais, sentindo-se eles próprios inseguros, e antipática a justiça.

Na mesma passada, GIUSEPPE BETTIOL ${ }^{165}$, após advertir que o princípio do favor rei é um princípio básico de toda legislação processual penal inspirada em sistema jurídico que tem como cláusula reitora a proteção do direito de liberdade, conclui que "En la contraposición entre el ius puniendi del Estado, de um lado, y el ius libertatis del imputado,

\footnotetext{
${ }^{160}$ A pena restritiva de direitos, muito embora não suprima o direito de liberdade, tem o condão de restringi-lo e, de qualquer sorte, arranha a imagem da pessoa.

161 Op. cit., p. 529.

162 Ibid.

163 Op. cit., p. 292.

164 Ibid., p. 292-293.

165 Op. cit., p. 262.
} 
del outro, la preeminência debe ser atribuída a este último si quiere que el valor de la libertad sea el que triunfe."

Como foi ressaltado, o fundamento do sistema democrático-constitucional brasileiro se pauta pela preservação do direito de liberdade, de modo que este, e não o direito de punir, é que merece tratamento mais atencioso por parte do legislador e do operador jurídico. Em homenagem à escolha política de privilegiar-se o direito de liberdade em detrimento mesmo da persecutio criminis, quebra-se a igualdade de tratamento das partes, com a imposição ao Ministério Público de buscar a verdade material no processo, enquanto para o acusado a verdade formal é bastante para a sua absolvição.maior do sistema, a ponto de autorizar o juiz a decidir em seu favor, sempre que ele estiver com dúvida quanto à culpabilidade.

A pertinência desse entendimento aqui defendido resultou expressamente ressaltada, à unanimidade, pelo Tribunal Pleno do Supremo Tribunal Federal, no julgamento do HC 80.263-SP, no qual foi relator o Ministro ILMAR GALVÃO ${ }^{166}$, tendo assim ficado redigida a ementa, na parte que interessa ao assunto em foco:

(...) a Lei Maior impõe a prevalência do direito à liberdade em detrimento do dever de acusar. Nesse contexto, princípios como o do devido processo legal e o do juízo natural somente podem ser invocados em favor do réu e nunca em seu prejuízo.

Por conseguinte, o princípio da presunção de não culpabilidade resulta em desequilíbrio da igualdade das partes na relação processual criminal, ao conferir a prevalência do direito à liberdade em detrimento do dever de acusar, o que, aliás, é uma decorrência lógica da função limitadora da pretensão punitiva desempenhada pelos direitos fundamentais, desde as suas primeiras formulações como declarações de direitos do homem, essência que permanece hígida nos sistemas democráticos.

\section{O ALCANCE DO PRINCÍPIO DA PRESUNÇÃO DE NÃO CULPABILIDADE}

Cabe indagar se o princípio da presunção de não culpabilidade vigora, com toda a sua higidez, durante todo o trâmite do processo criminal ou se sofre variações, conforme as sucessivas etapas. A primeira questão que se apresenta é quanto à dicção normativa empregada pelo constituinte na declaração do princípio: "Ninguém será considerado culpado até o trânsito em julgado de sentença pena condenatória" (art. 5, LVII, da Constituição). À primeira vista, o alcance do dispositivo é sobremaneira elástico, mantendo-se hígido em todo

\footnotetext{
${ }^{166}$ HC 80.263-SP, Tribunal Pleno, Rel. Ministro ILMAR GALVÃO, j. 20.02.2003, DJ de 27.06.2003, p. 30.
} 
o curso do processo, sem nenhum tipo de variação quanto às fases, exceto quando da execução da sentença condenatória.

Não se discute que a presunção de não culpabilidade em si do agente em relação a um determinado caso só se extingue com o trânsito em julgado do pronunciamento judicial condenatório.

De toda sorte, apresenta-se em sintonia com o preceito constitucional em causa a assertiva de que a presunção dele oriunda só detém toda a sua elasticidade e alcance em relação a uma pessoa, enquanto não houver um juízo de culpabilidade contra ela. Dessa forma, ainda que a decisão na qual se escora o juízo de culpabilidade seja passível de desconstrução mercê do provimento de pretensão recursal eventualmente interposta, uma coisa é certa: a presunção de não culpabilidade foi quebrada, pois um juiz, com observância do devido processo legal, considerou o acusado culpado, afastando dúvida razoável quanto a essa conclusão. Em compasso com essa linha de raciocínio, o Criminal Procedure Code americano, aplicável a todos os Estados, deixa claro, no art. 16, que "se deve presumir inocente o acusado até que o oposto seja estabelecido em um veredicto efetivo".

Notadamente caso esse juízo de culpabilidade esteja firmado em decisão de tribunal de segundo grau, instância que, em nosso meio, exaure a jurisdição de partes. Pode-se dizer, assim, que, em rigor, quanto aos aspectos factuais, verifica-se o trânsito em julgado a partir da decisão de segundo grau.

Nessa linha de entendimento, mostra-se plenamente compatível com o princípio da presunção de não culpabilidade a previsão de que os efeitos de preceito condenatório se façam sentir quando oriundo de decisão de órgão colegiado de segundo grau, como ocorre quanto à caracterização de ficha suja como causa de inelegibilidade para participar de certame eleitoral para fins de provimento de cargo eletivo ${ }^{167}$.

Ressalte-se que, consoante esmiuçado no item supra, não se tem conhecimento, seja no Direito Comparado, seja nas declarações internacionais, de que o princípio da presunção de inocência ou da não culpabilidade compreenda o entendimento de que nenhum efeito de sentença condenatória possa se fazer sentir senão após o trânsito em julgado do processo. E não há simplesmente porque seria ilógico, ademais de não parecer razoável defender que assim seja.

\footnotetext{
${ }^{167}$ Nesse sentido, cabe observar que o art. $1^{\circ}$, I, alínea $e$, da Lei Complementar $\mathrm{n}^{\circ}$ 64, de 1990 , com a redação dada pela Lei Complementar $\mathrm{n}^{\circ} 135$, de 2010, define que são inelegíveis os que forem condenados em decisão profeirda por órgão judicial colegiado, nos crimes que especifica.
} 
Há de se ter em conta a regra de hermenêutica constitucional vazada na afirmação de que o constituinte, por ter como foco ditar preceitos de conteúdo político ${ }^{168}$, não emprega as palavras necessariamente conforme a expressão técnico-jurídica dos diversos ramos do direito. Por isso mesmo, a orientação prevalente no Supremo Tribunal Federal, mesmo após a Constituição de 1988, conforme se verifica do julgamento em 1991, sempre foi no sentido de que

(...) Mantida, por unanimidade, a sentença condenatória contra a qual o réu apelara em liberdade, exauridas estão as instâncias ordinárias criminais, não sendo, assim, ilegal o mando de prisão que o órgão julgador de segundo grau determina se expeça contra o réu." (HC 68,726, Rel. Ministro Néri da Silveira)

Existe registro da manutenção desse entendimento até o julgamento do Habeas Corpus no 91.675, julgado pela Primeira Turma e publicado no DJ em 7 dez. 2007, com a parte substancial da ementa elaborada pela Ministra Cármen Lúcia apresentando o seguinte teor:

(...) 1. A jurisprudência deste Supremo Tribunal Federal é firme no sentido de ser possível a execução provisória da pena privativa de liberdade, quando os recursos pendentes de julgamento não têm efeito suspensivo.

Essa posição tradicional da jurisprudência da Corte Suprema, todavia, foi alterada pelo Plenário em 5 de fevereiro de 2009, no julgamento do Habeas Corpus 84.078/ $\mathrm{MG}^{169}$, quando, por uma maioria de sete votos a quatro ${ }^{170}$, os ministros definiram, em obséquio ao princípio da presunção de não culpabilidade, a impossibilidade da prisão como efeito da sentença antes do trânsito em julgado.

A ementa do acórdão do referido leading case foi redigida pelo Ministro Eros Grau, merecendo menção a seguinte parte:

(...) 8. Nas democracias mesmo os criminosos são sujeitos de direitos. Não perdem essa qualidade, para se transformarem em objetos processuais. São pessoas, inseridas entre aquelas beneficiadas pela afirmação constitucional da sua dignidade (art. $1^{\circ}$, III, da Constituição do Brasil). É inadmissível a sua exclusão social, sem que sejam consideradas, em quaisquer circunstâncias, as sigularidades de cada infração penal, o que somente se pode apurar plenamente quando transitada em julgado a condenação de cada qual Ordem concedida.

\footnotetext{
${ }^{168}$ A expressão "político" aqui está grafada na acepção mais grega da palavra. É na mesma consideração de que a Constituição se constitui em uma Carta Política.

${ }^{169}$ Supremo Tribunal Federal. Disponível em www.stf.jus.br. Data do julgamento: 17 fev. 2016. Acesso em: 04 out. 2017.

${ }^{170}$ Ficaram vencidos os Ministros Menezes Direito, Cármen Lúcia, Joaquim Barbosa e Ellen Gracie. O Relator Eros Grau foi acompanhado pelos Ministros Celso de Mello, Marco Aurélio, Gilmar Mendes, Cezar Peluso, Carlos Britto e Ricardo Lewandowski.
} 
Essa nova orientação jurisprudencial do Supremo Tribunal Federal foi por nós criticada na segunda edição do livro Curso de processo penal: teoria (constitucional) do processo penal. Ademais de não haver precedente do Direito Comparado, a nova orientação se mostrava de todo inadequada no cenário nacional, cuja arquitetura complexa do judiciário contempla a existência de quatro instâncias, de modo que esse entendimento, no mínimo, gerava sensação de impunidade.

Diante da inadequação dessa nova posição da Corte Suprema, não tardou de ocorrer a reviravolta no entendimento sobre o tema. De fato, no mês em que a nova orientação jurisprudencial do Supremo completou sete anos, mais precisamente em 17 de fevereiro de 2016, a Corte, quando do julgamento do Habeas Corpus no 126.292/SP, voltou à posição. Por maioria, vencidos os Ministros Rosa Weber, Marco Aurélio, Celso de Mello e Ricardo Lewandowski ${ }^{171}$, em voto da relatoria do Ministro TEORI ZAVASCKI ${ }^{172}$, o Plenário do Supremo Tribunal Federal, deixou plasmada a seguinte posição:

A execução provisória de acórdão penal condenatório proferido em grau de apelação, ainda que sujeito a recurso especial ou extraordinário, não compromete o princípio constitucional da presunção de inocência afirmado pelo artigo $5^{\circ}$, inciso LVII da Constituição Federal. (...)

No desiderato de firmar a posição sobre a matéria e, de permeio, guiar as decisões nas demais instâncias judiciais, o Tribunal Excelso, em regime de repercussão geral, no julgamento do RE 964.246/SP ${ }^{173}$, reafirmou a jurisprudência no "sentido de que a execução provisória de acórdão penal condenatório proferido em grau recursal, ainda que sujeito a recurso especial ou extraordinário, não compromete o princípio constitucional da presunção de inocência afirmado pelo art. $5^{\circ}$, inciso LVII, da Constituição Federal”.

Observa-se desse bosquejo histórico, que a jurisprudência do Supremo Tribunal Federal sobre o alcance do princípio da presunção de não culpabilidade, exceto durante o lapso temporal compreendido entre fevereiro de 2009 a fevereiro de 2016, sempre foi no sentido de que os efeitos da decisão condenatória quanto ao cumprimento de eventual pena aplicada têm início logo após o julgamento pela instância de segundo grau, sem embargo da dicção normativa encartada no art. $5^{\circ}$, inciso LVII, da Constituição.

\footnotetext{
${ }^{171}$ Acompanharam o Relator Teori Zavascki os Ministros Gilmar Mendes, Cármen Lúcia, Dias Tófolli, Luiz Fux, Rosa Weber, Roberto Barroso e Edson Fachin.

${ }^{172}$ Supremo Tribunal Federal. Disponível em www.stf.jus.br. Data do julgamento: 17 fev. 2016. Acesso em: 04 out. 2017.

${ }^{173}$ Supremo Tribunal Federal. Disponível em www.stf.jus.br. Data do julgamento: 17 fev. 2016. Acesso em: 04 out. 2017.
} 
Estreme de dúvidas a posição atual, ademais de retomar o entendimento que é da tradição de nosso sistema jurídico e estar em sintonia com o Direito Comparado, se revela a mais aceitável. Até porque o acusado poderá, sempre e sempre, conforme o caso, diante das singularidades, pedir na pendência da interposição ou apreciação de recurso especial ou extraordinário, que seja emprestado efeito suspensivo ao pleito recursal, com suporte no art. $1.029, \S 5^{\circ}$, do $\mathrm{NCPC}^{174}$.

Isso sem contar que o Ministro Teori Zavascki salientou, em seu voto, que a defesa pode se utilizar, ainda, do habeas corpus, quando tiver fundamentos relevantes que apontem a temeridade do prematuro recolhimento à prisão, solicitando, assim, que seja concedida liminar no escopo de sustar a execução provisória.

No entanto, infelizmente, alguns Ministros do próprio Supremo Tribunal, contrariando a repercussão geral do julgado, em decisões monocráticas, têm decidido que é incompatível com o princípio da presunção de não culpabilidade a execução provisória antes do trânsito em julgado. Ademais, no julgamento do habeas corpus preventivo $\mathrm{n}^{\circ} 152.752$, impetrado em nome do ex-presidente Luís Inácio Lula da Silva, malgrado o Supremo Tribunal Federal, por maioria de um voto, tenha mantido o novo entendimento sobre o alcance do princípio da presunção de não culpabilidade, foi lançado o indicativo ${ }^{175}$ de que, quando do julgamento da Ação Direta de Constitucionalidade sobre o art. 312 do Código de Processo Penal, será alterada uma vez mais a jurisprudência a respeito do tema, provavelmente para ser firmada a posição de que o cumprimento da pena só poderá ter início após eventual julgamento do Superior Tribunal de Justiça, tese agitada pelo Ministro Dais Toffoli.

\section{CONSIDERAÇÕES FINAIS}

A primeira Constituição brasileira a inserir o princípio dentre os direitos fundamentais foi a de 1988, sendo patente, diante da dicção normativa emprestada ao inciso LVII do art. $5^{\circ}$,

\footnotetext{
${ }^{174}$ O NCPC revogou os arts. 26 a 29 da Lei ${ }^{\circ}$ 8.038, de 1990, que disciplinavam os recursos extraordinário e especial. Assim, hoje, os recursos extraordinário e especial na matéria criminal estão regulados no NCPC. O pedido de efeito suspensivo deve ser dirigido (a) ao tribunal superior respectivo, se solicitado no período compreendido entre a publicação da decisão de admissão do recurso e sua respectiva distribuição; (b) ao relator, se já distribuído o recurso; e (c) ao presidente ou vice-presidente do tribunal recorrido, conforme estabelecido no respectivo regimento interno, se solicitado no período compreendido entre a interposição do recurso e a publicação da decisão de admissão do recurso (art. 1.029, §5 , incisos I, II e III, do NCPC).

${ }^{175}$ Ocorreu o que na cultura dos precentes a doutrina denomina sinaling. Essa circunstância ficou clara no teor do voto da Ministra Rosa Weber, que, invocando o princípio da segurança jurídica, manteve o entendimento do colegiado, porém, sinalizou que modificará o seu entendimento, quando a matéria for discutida na ADC.
} 
a influência das Cartas Magnas dos Estados Unidos e da Itália, pois, expressamente, fala-se em presunção de não culpabilidade.

Com suporte na ideia do transconstitucionalismo, o diálogo da ordem jurídica nacional com o Direito Comparado e, especialmente, com as declarações internacionais permitem a conclusão de que incidem em nosso ambiente tanto o princípio da presunção de inocência quanto o da não culpabilidade.

Em rigor, o princípio da presunção de inocência é o gênero do qual são suas espécies o princípio da presunção de inocência stricto sensu e o da não culpabilidade. O princípio da presunção de inocência em sentido estrito se traduz no binômio justa causa, que significa a proteção da dignidade da pessoa humana quanto a sua honra e a imagem, na medida em que impõe limite à persecução criminal, não podendo a autoridade policial indiciar alguém, o Ministério Público oferecer a ação penal e o juiz receber esta, sem que se tenha uma culpa sumária formada, constituída pela prova sobre a materialidade do ilícito e de indícios da autoria. Assim, quando o juiz vai decidir sobre a admissibilidade da ação penal, questões interlocutórias ou mesmo sobre a absolvição sumária, o princípio aplicável é o da presunção de inocência, razão pela qual ele não precisa se apoiar em certeza material para decidir contra os interesses dos acusados.

A incidência do princípio da presunção da não culpabilidade desequilibra a relação processual, pois, em razão dele, o Ministério Público tem o dever de provar, enquanto para a defesa se mostra suficiente suscitar dúvida razoável (in dubio pro reo), o que quer dizer que, conquanto a sentença condenatória só seja admissível com suporte em verdade material, para a absolutória basta que exista uma dúvida razoável, ou seja, pode ser proferida igualmente com fulcro na verdade formal.

A jurisprudência tradicional do Supremo Tribunal Federal, mesmo após a Constituição de 1988, sempre foi no sentido de que o princípio encartado no art. $5^{\circ}$, inciso LVII, da Constituição, não é empecilho à execução provisória, sendo alterada, apenas, em 2009, tendo a Excelsa Corte, ao enxergar a sua inadequação e ausência de respaldo no Direito Comparado, voltado à posição anterior já em 2016.

Espera-se que o Supremo Tribunal Federal, a despeito dos interesses em jogo, não volte, no ponto, a modificar a sua jurisprudência, até porque, não há nada de novo a justificar a alteração, sem embargo de outra reviravolta quanto ao tema ter o condão de comprometer de forma severa a segurança jurídica e a ideia de implantação efetiva de um sistema vazado no respeito aos precedentes judiciais. 


\section{REFERÊNCIAS}

BARROS; Romeu Pires de Campos. Sistema do processo penal brasileiro. Rio de Janeiro: Forense, 1990.

BECCARIA, Cesare. Dos delitos e das penas. Tradução Marcílio Teixeira. Rio de Janeiro: Editora Rio.

BETTIOL, Giuseppe. Instituciones de derecho penal y procesal. Tradução de Faustino Gutiérrez-Alviz y Conradi. Barcelona: Bosch Casa Editorial, 1973.

BRITO, Carla Maria Fernandes. Arcabouço teórico do princípio da não culpabilidade no sistema jurídico penal brasileiro. 2003. 61f. Especialização (Especialização em Direito) - Especialização em Direito, Escola da Magistratura do Rio Grande do Norte, Natal, 2003.

CARRARA, Francesco. Programa do curso de direito criminal. Tradução de Ricardo Rodrigues Gama. Campinas: Editora LZN, 2002.

CARVALHO, Luiz Gustavo Grandinetti. O processo penal em face da constituição. Rio de Janeiro: Forense.

COMPARATO, Fábio Konder. A afirmação história dos direitos humanos. São Paulo: Saraiva, 1999.

HIMÉNEZ, Londoño, Tratado de derecho procesal penal. Bogotá: Editorial Temis, 1989. t. 1.

MAIEROVITCH, Wálter Fanganiello. Presunção de não culpabilidade. In: Revista de Jurisprudência do Tribunal de Justiça do Estado de São Paulo. n. 126.

MENDES, Gilmar Ferreira; BRANCO, Paulo Gustavo Gonet. Curso de direito constitucional. 6. ed. São Paulo: Saraiva, 2007

MOURA, Maria Thereza Rocha de Assis. Justa causa para a ação penal: doutrina e jurisprudência. São Paulo: Revista dos Tribunais, 2001.

NEVES, Marcelo. Transconstitucionalismo. São Paulo: Editora WMF Martins Fontes, 2009.

RUBIANES, Carlos. Manual de derecho procesal penal. Buenos Aires: Depalma, 1985. v 1. 
SILVA JÚNIOR. Walter Nunes da. Curso de processo penal: teoria (constitucional) do processo penal. 2. ed. Natal: OWL, 2015.

Reforma tópica do processo penal: inovações aos procedimentos ordinário e sumário, com o novo regime das provas, principais modificações do júri e as medidas cautelares pessoais (prisão e medidas diversas da prisão), 2. ed. Rio de Janeiro: Editora Renovar.

VILE. John R. A companion to the united states constitution and its amendments. 3. ed. Library of Congress Cataloging-in-Publication Data, 2001.

\title{
PRINCIPLES OF THE PRESUMPTION OF INNOCENCE AND NON- CULPABILITY: DISTINCTION, APPLICATION AND SCOPE
}

\begin{abstract}
While it is a universal principle inherent in legal systems in general, the presumption of innocence or non-culpability was only foreseen in Brasil in the category of fundamental right in the Constitution of 1988. Even so, before the normative diction employed by the constituent, there is debate on doctrine and jurisprudence, especially regarding the effective nomenclature of the constitutional clause and its scope. The dialogue with Comparative Law leads to the conclusion that, in truth, our system embodies the principle of the presumption of innocence as a genus, having as its species the principles of presumption of innocence stricto sensu and that of non-guilt. In summary, the first, in protection of the honor and image of the people, prevents that there is the indictment, the filing of the criminal action or the receipt of the criminal action without the existence of a sumary evidence materiality and indications of authorship; the second, is made in relation to judicial pronouncements, when, with the decision, the judge can plead guilty. The principle of the presumption of innocence applies more directly to the actions of the police authority and the Public Prosecutor's Office, also focusing on the decisions of the judge in which the merits are not considered. The principle of presumption of non-culpability, however, governs the judge's action, from which parenia derives in dubio pro reo, if and as long as there is no guilty verdict, especially in case of conviction by court, that exhausts the discussion of the factual matter .
\end{abstract}

Keywords: Presumption of innocence. Presumption of nonculpability. Distinction. Incidence. Extension. 